\title{
Fear of Ebola epidemics in Bangladesh: Issues and approaches
}

\author{
Rabiul Ahasan
}

\begin{abstract}
Associate Professor, Institute for Community Development and Quality of Life, Faculty of Medicine and Health Sciences,
\end{abstract} Universiti Sultan Zainal Abidin, Malaysia.

The Ebola virus is the cause of a viral hemorrhagic fever currently killing people in West Africa. ${ }^{1}$ Bengali speaking people currently are living in the affected region including hundreds of military peacekeepers from Bangladesh. BGMEA is dealing with taking orders and shipments of garments in Africa. ${ }^{2}$ There are business people and Bangladeshi farmers leasing agricultural lands in some parts of Africa. ${ }^{3,4}$ It is thus imperative that the virus might travel to Bangladesh through our peacekeepers or others currently working and living in various parts of Africa including Congo, Liberia, Guinea, and Sierra Leone. The deadly virus could spread at an alarming rate unless emergency steps are seriously taken to contain and stop it. ${ }^{5}$

The World Health Organization (WHO) has declared an international health emergency, since the Ebola virus outbreak leads to a fatal disease. ${ }^{6}$ Bangladesh, however, is on the list of least threatened countries compared to other developing countries. ${ }^{7}$ Until now, no Bangladeshi people have been infected according to the Institute of Epidemiology, Disease Control and Research (IEDCR). It does not, however, mean that there is no chance of getting the infection. Currently an Ebola diagnostic facility is not available in Bangladesh, however, IEDCR $^{8}$ have the capacity of sending samples within 24 hours to CDC or to WHO Collaborative Centers. ${ }^{9,10}$

The Inter Services and Personnel Recruitment (ISPR) authorities are in constant touch with all concerned authorities including the UN Mission in Africa. All UN Missions in West Africa ${ }^{11}$ are provided with some form of emergency response to Ebola. And thus, Bangladeshi peacekeepers deployed in Liberia and Sierra Leone have been asked to stay in a restricted area. As a measure of precaution against the Ebola outbreak, Bangladeshi peacekeepers have already received personal protective equipment (e.g. gloves, masks, respirators, and aprons) from the national disease monitoring arm, such as IEDCR. The health directorate has been urging everyone not to spread panic because it may cause an overreaction. ${ }^{8}$ The Bangladesh Armed Forces is monitoring the situation and maintaining constant contact with all concerned, including the UN HQ in Nairobi. ${ }^{11}$ The government has issued a 90-day health alert for the Ebola virus. In the mean time, a 20-bed unit has been opened up at the Kurmitorla General Hospital $^{12}$ to quarantine and treat suspected Ebola patients, if any. Bangladesh does not have enough resources to establish a central disease control system like those that exist in western countries, but public health officers as well as private and government hospitals are on alert.

Clinicians understand the public's fear and anxiety regarding Ebola since the disease has no known vaccine and the known cure is uncertain. ${ }^{6,7}$ Thus, prevention is better than cure. It is however difficult for the public health and other concerned departments to manage the situation at the source. The risk cannot be overlooked although IEDCR may have taken prerequisite steps to prevent the deadly virus. As part of precautions and emergency response plan, medical teams should monitor all the air, land and sea ports. For this, coordinated team work is important due to its nature of surveillance. General practitioners, nurses, and community health officials are to be trained to prevent an Ebola outbreak. Till now the outbreak has not moved across the border but controlling the deadly virus will be difficult in terms of looking for infected patients among the thousands of travelers coming in and going out of the country. In the mean time, a committee has been formed, headed by the Health Secretary, to oversee the surveillance, but emergency preparedness, vigilance, and community awareness are still lacking behind. Overall, it needs coordinated involvement of various government departments and officials that is perhaps a daunting task in the context of third world culture. ${ }^{13-16}$

Against an Ebola outbreak, various measures ${ }^{17}$ were recommended by the WHO. It may require a local surveillance system ${ }^{18}$ and a proper management plan $^{19}$ as quickly as possible. A national effort is also important to support ${ }^{20}$ an internationally coordinated response to deal with Ebola. The officials should have high morale in this type of situation, and they should keep themselves ethically standard. Unlike the disaster at Rana Plaza, ${ }^{21}$ the garment factory that seriously collapsed in Dhaka (Bangladesh), the concerned authorities should not delay any emergency plan against Ebola.

In such an emotional climate surrounding the intense fear of Ebola, ${ }^{22}$ too many people are claiming to have cures on social media. Twitter is full of individuals claiming to know of curing Ebola. ${ }^{22}$ Fraudulent cure claims on social media and rumors of any other effective products

Correspondence: Dr. Rabiul Ahasan, Associate Professor, Institute for Community Development and Quality of Life, Faculty of Medicine and Health Sciences, Universiti Sultan Zainal Abidin, Malaysia. E-mail: rabiulahasan123@gmail.com.

South East Asia Journal of Public Health 2014;4(1):1-3 (C) 2014. Ahasan, publisher and licensee Public Health Foundation Bangladesh. This is an Open Access article which permits unrestricted non-commercial use, provided the original work is properly cited. DOI: http://dx.doi.org/10.3329/seajph.v4i1.21829 
or practices are perhaps false and their use can be dangerous. Recent media coverage of experimental medicines and vaccines are creating some unrealistic expectations. $^{22}$ In Nigeria, for example, at least two people have died after drinking salt water that was rumored to be protective. There needs to be more reason when it comes to fervor over experimental drugs that are perhaps currently in limited supply. The public needs to understand that the majority of treatments available are not approved yet. The experimental drug 'ZMapp' is $100 \%$ effective in animal trials ${ }^{23}$ but a licensed vaccine is not expected before 2015 .

A clinical trial of an experimental vaccine is set to start by GSK (www.gsk.com). US scientists ${ }^{24}$ are developing the product alongside the British pharmaceutical industry. The US National Institutes of Health (www.nih.gov) is supporting the work of Johnson \& Johnson's Crucell unit on early-stage vaccines that are designed to give additional protection against Marburg $^{25,26}$ caused by a similar family virus. The $\mathrm{WHO}^{27}$ is developing usage guidelines from a panel of public health experts, microbiologists, and clinicians. The CDC is currently tracking cases to prevent further infections. ${ }^{9,28}$ The WHO panel deemed it ethical to use experimental drugs and or FDA approved vaccines ${ }^{29}$ during the outbreak, and therefore, an increasing pressure on scientists remain to accelerate their research on new medical interventions, against Ebola. Since it is an unexplained febrile illness consistent with potential viral infection, every country should participate in all the possible means of intervention. If these interventions are still weak in any developing country due to a lack of resources and financial constraints, the national disease monitoring unit should ask for international help. Keeping a constant watch on the Ebola situation worldwide, and monitoring local health programs (ongoing doctors' training, conducting surveillance, screening and diagnosis) will thus be benefited. It is also advised that any person in a particular country with an illness consistent with Ebola should not be allowed to travel to other country unless the travel is part of an appropriate medical evacuation. The absence of direct air links with the affected countries and travel restrictions on Ebola patients could stop the deadly virus making its way to other country.

\section{References}

1. Olival KJ, Islam A, Yu M, Anthony SJ, Epstein $\mathrm{JH}$, Khan SA, et al. Ebola virus antibodies in fruit bats-Bangladesh. Emerg Infect Dis 2013;19(2): 270-3.

2. Bangladesh Garments Manufacturing and Exporters Association (BGMEA). Garments export to US may lose out to Africa. The Daily Star. Aug 29, 2014. http://www.thedailystar.net/ garment-exports-to-us-may-lose-out-to-africa$\underline{39138}$ (accessed June 2014)

3. Macchiavello R. Manufacturing in Africa: perspective from Bangladesh ready made garments. http://www.theigc.org/sites/default/ f i 1 e s / s e s s i o n s / R o c c c o o \% 20Macchiavello Industry AGF2013.pdf (accessed June 2014)

4. Ethirajan A. Bangladeshi Companies Launch Africa Farm Lease Plan. BBC News. 17 May 2011). http://www.bbc.co.uk/news/world-southasia-13428867 (accessed June 2014)

5. The Hindu. Bangladesh Issues Ebola Alert. The Hindu. 11 Aug 2014. http://www.thehindu.com/ news/international/south-asia/bangladesh-issuesebola-alert/article6303969.ece (accessed June 2014)

6. Chai C. Ebola: What the WHO's International Health Emergency Declaration Means? Global News. http://globalnews.ca/news/1499571/ebolawhat-the-whos-international-health-emergencydeclaration-means/ (accessed June 2014)

7. World Health Organization. Ebola Virus Diseases. Fact Sheet No 103. http:// www.who.int/mediacentre/factsheets/fs103/en/ (accessed June 2014)

8. Institute of Epidemiology, Disease Control \& Research (IEDCR). Disease surveillance in Bangladesh: moving towards e-system. http:// w w w i a n p h i.org/d o c u m e n t s / bangladeshpresentation (accessed June 2014)

9. Centers for Disease Control \& Prevention (CDC). CDC in Bangladesh. Atlanta: CDCAtlanta, 2014.

10. World Health Organization. WHO Collaborating Centers for influenza and essential regulatory laboratories. http://www.who.int/influenza/ gisrs laboratory/collaborating_centres/list/en/ (accessed June 2014)

11. UN HQ in Africa. Welcome to the United Nations Office at Nairobi. http://www.unon.org/ (accessed June 2014)

12. Nasiruddin AMK. Kurmitola General Hospital committed to serve the people of all walks of life. The Guardian. June 5, 2014. http:// www.theguardianbd.com/kurmitola-generalhospital-committed-to-serve-the-people-of-allwalks-of-life/ (accessed June 2014)

13. Zafarullah H, Rahman R. The impaired state: assessing state capacity and governance in Bangladesh. Intl J Pub Sect Mangt, 2008;21 (7):739-52.

14. Ades A, Di Tella R. Competition and Corruption (working paper). Institute of Economics and Statistics. London: Oxford University Press, 1994.

15. Greenaway J. Having the Bun and the Halfpenny: can old public service ethics survive in the new Whitehall? Pub Admn 1995;73(3):35774.

16. Grindle MS. Divergent cultures — when public 
organizations perform well in developing countries? World Dev 1997;25(4):481-95.

17. World Health Organization. Interim Infection Prevention and Control Guidance for Care of Patients with Suspected or Confirmed Filovirus Haemorrhagic Fever in Health-Care Settings, with Focus on Ebola. Geneva: WHO, 2014.

18. Geneva Health Forum. Chronic Disease Surveillance System in Bangladesh. http:// ghf.g 2 hp.net/2011/12/07/2143/ \#.VAPLF8WSxvA (accessed June 2014)

19. Management Sciences for Health Services in Bangladesh. http://www.msh.org/our-work/ country/bangladesh (accessed June 2014)

20. Chowdhury JH, Bhuiyan MUA, Hasan MM, Sultana T. Support to the Health, Nutrition and Population Sector Program in Bangladesh. Dhaka: RTM International, 2012.

21. Gomes W. Reason and responsibility: the Rana Plaza collapse. Open Security. May 9 2013 .https://www.opendemocracy.net/ opensecurity/william-gomes/reason-andresponsibility-rana-plaza-collapse (accessed June 2014)

22. World Health Organization. Ebola: Experimental therapies and rumoured remedies — situation assessment. http://www.who.int/mediacentre/ news/ebola/15-august-2014/en/ (accessed June 2014)
23. Gallagher J. Ebola: Experimental drug ZMapp is $100 \%$ effective in animal trials. $B B C$ News. 29 Aug 2014. http://www.bbc.com/news/health28980153 (accessed June 2014)

24. US Today. US Officials Announce Ebola Vaccine Trial Launch. http://www.usatoday.com/ story/news/nation/2014/08/28/ebola-vaccinetrial/14716833/ (accessed June 2014)

25. Pattyn S, Jacob W, van der Groen G, Piot P, Courteille G. Isolation of Marburg-like virus from a case of haemorrhagic fever in Zaire. Lancet 1977; 309(8011):573-4.

26. Klenk HD, Feldmann H (ed.). Ebola and Marburg viruses: molecular and cellular biology. Norfolk: Horizon Bioscience, 2004.

27. World Health Organization. Vaccination Regulations (Immunization standards). http:// www.who.int/immunization standards/ vaccine_regulation/en/ (accessed June 2014)

28. Centers for Disease Control and Prevention. Ebola Virus Disease Information for Clinicians in U.S. Healthcare Settings. http://www.cdc.gov/ vhf/ebola/hcp/clinician-information-ushealthcare-settings.html (accessed June 2014).

29. U.S. Food and Drug Administration. Vaccine, Blood \& Biologics. http://www.fda.gov/ biologicsbloodvaccines/vaccines/ approvedproducts/ucm093830.htm (accessed June 2014) 